\title{
UPAYA MEREKONSTRUKSI ULANG PENDIDIKAN NASIONAL
}

\author{
Ali Nupiah \\ Program Studi Pendidikan Agama Islam, Jurusan Tarbiyyah STAIN Batusangkar \\ Korespondensi: Jorong Tabek, Nagari Tabek, Kecamatan Pariangan, Kabupaten Tanah Datar
}

\begin{abstract}
Low quality of human resources in Indonesia can be separated from crucial problems that have not been solved until today. In general, those problems deal quality, distribution, relevance, efficiency and effectiveness of education. High rate of unemployment is indicates low relevance of education and the society's demand. Consequently, curriculum development should provide the pupils with the ability to reach expected standard of life. Therefore, curriculum should be able to reflect real life which constantly develops and prepares the pupils to face and take part in any changes. Dealing with the demand, pupils should be provided with basic life skills and instrument skills. Those skills will be elaborated into competency in curriculum development and becomes the goals to be achieved in learning process and evaluation.
\end{abstract}

Kata kunci: merekonsruksi ulang, pendidikan, nasional

\section{PENDAHULUAN}

1 khir-akhir ini muncul fenomena yang menarik untuk dicermati kalangan pendidikan. Banyak lulusan SLTP, SLTA, bahkan Perguruan Tinggi tidak tahu apa yang harus dikerjakan, kecuali meneruskan atau mencari pekerjaan dengan bekal selembar ijazah. Bahkan ketika masih sekolahpun, mereka seperti tidak lagi tahu apa yang harus dikerjakan di rumah, kecuali bermain dan maksimal mempelajari buku pelajaran. Siswa SLTA yang sudah sekian tahun belajar Biologi, Matematika, Ekonomi dan sebagainya, menjadi kebingungan ketika harus merancang masakan yang bergizi tetapi harganya murah. Seorang sarjana tidak termotivasi untuk mencari pemecahan, ketika dihadapannya banyak sampah yang menumpuk, kecuali mengeluhkan kerja petugas pengangkut sampah. Siswasiswa SLTA asyik bercengkrama ber- sama teman-temannya, sementara orang tua mereka mandi keringat mengolah sawah. Seakan-akan mata pelajaran itu hanya ada di buku dan tidak terkait dengan kehidupan sehari-hari.

Apalagi jika dihadapkan pada tantangan ke depan dengan adanya kesekapatan perdagangan bebas AFTA dan AFLA telah bergulir dengan membawa konsekuensi membuka peluang masuknya tenaga kerja dari luar negeri yang berkualitas dan berdaya saing tinggi ke dalam dunia kerja di Indonesia. Hal ini jelas mengancam keberadaan tenaga kerja Indonesia, lebih-lebih bagi mereka yang tidak memiliki kecakapan hidup yang memadai untuk memasuki kesempatan kerja yang ada (Abuddin Nata, 2009:13). Kenyataan ini mengimplikasikan bahwa keterbukaan negara dan masyarakat Indonesia terhadap berbagai aktivitas sosial, ekonomi, budaya dan komunikasi telah menuntut tersedianya modal sumber daya manusia 
berupa kecakapan hidup yang bermutu dan mampu bersaing dengan tenaga kerja asing.

Hal lain yang perlu mendapat perhatian adalah banyaknya siswa SLTP yang amat rentan dengan droup out karena kondisi ekonomi yang sulit dan banyak tamatan SLTP yang terpaksa harus menjadi penganggur karena tidak mendapatkan lapangan pekerjaan dan juga merasa kesulitan untuk menerapkan pengetahuan yang diperoleh di sekolah dalam kehidupan nyata. Hal yang demikian menuntut dunia pendidikan melakukan intropeksi pada pola pembelajaran yang dikembangkan di sekolah karena selama ini pembelajaran yang dikembangkan di sekolah bersifat teoritis.

Masalah di atas masih ditambah lagi dengan fakta bahwa sebagian besar tamatan pendidikan dasar dan menengah umum tidak dapat terserap ke dalam dunia kerja. Faktor-faktor penyebabnya antara lain adalah: (1) jumlah angka kerja yang hanya tamatan pendidikan dasar dan menengah umum jauh lebih besar daripada kesempatan kerja yang ada. (2) angkatan kerja tamatan pendidikan dasar dan menengah umum kalah bersaing dengan angkatan kerja tamatan pendidikan menengah kejuruan dalam memasuki lapangan kerja, karena kecakapan yang mereka miliki sangat minim dan terbatas, (3) kecapakan hidup yang dibutuhkan oleh masyarakat luas khususnya dunia kerja yang ada di masyarakat tidak sesuai dengan kecakapan yang dimiliki tamatan pendidikan dasar dan menengah umum (Saryono, Djoko, 2002). Hal-hal tersebut menyebabkan para lulusan pendidikan dasar dan menengah di Indonesia tidak memiliki keunggulan komperatif, apalagi keunggulan kompetitif.

Bertolak dari berbagai gambaran di atas, dapat dilihat bahwa ada permasalahan besar dan mendasar dengan pe- nyelenggaraan pendidikan di Indonesia yaitu rendahnya mutu sistem pembelajaran atau sistem pendidikan di sekolah. Oleh sebab itu, perlu dilakukan pengembangan sistem pendidikan yang dalam hal ini pengembangan kurikulum yang mampu mengatasi persoalanpersoalan tersebut.

\section{KECAKAPAN HIDUP}

Menurut Indrajati Sidi (2002), kecakapan hidup adalah kecakapan yang dimiliki seseorang untuk mampu menghadapi problema hidup dan kehidupan secara wajar tanpa merasa tertekan, kemudian secara proaktif mencari serta menemukan solusi sehingga akhirnya mampu mengatasinya. Dalam pandangan Slamet PH (2002), kecakapan hidup adalah pendidikan kemampuan, kesanggupan dan keterampilan yang diperlukan oleh seseorang untuk menjalankan kehidupan dengan nikmat dan bahagia. Sedangkan Brolin (1989) mengemukakan bahwa kecakapan hidup merupakan pengetahuan dan kemampuan yang dibutuhkan oleh seseorang untuk berfungsi dan bertindak secara mandiri dan otonom dalam kehidupan sehari-hari, tidak harus selalu meminta bantuan dan petunjuk pihak lain. Ini berarti bahwa bentuk kecakapan hidup berupa pengetahuan sebagai praktis dan kita (praxis dan techne), bukan teori: pengetahuan sebagai skills of doing sekaligus skills of being.

Pendidikan berjalan pada setiap saat dan pada segala tempat. Setiap orang dari kanak-kanak hingga tua mengalami proses pendidikan melalui apa yang dijumpai atau apa yang dikerjakan. Walaupun tidak ada pendidikan yang sengaja diberikan, secara alamiah setiap orang akan terus belajar dari lingkungannya. Pendidikan diartikan sebagai proses perolehan pengalaman belajar yang berguna bagi 
peserta didik. Apabila dikaitkan dengan life skills maka pendidikan sebagai sistem yang pada dasarnya merupakan sistematisasi dari proses perolehan pengalaman. Oleh karena secara filosofis pendidikan diartikan sebagai proses pengalaman belajar yang berguna bagi peserta didik. Pengalaman belajar tersebut diharapkan mampu mengembangkan potensi yang dimiliki peserta didik, sehingga siap digunakan untuk memecahkan problema dalam kehidupan yang dihadapi. Pengalaman yang diperoleh diharapkan dapat mengilhami mereka ketika menghadapi problema dalam kehidupan sesungguhnya.

Tahun 2001 Pemerintah Pusat, dalam hal ini Departemen Pendidikan Nasional mengembangkan konsep Pendidikan Kecapakan Hidup (Life Skills Education), yaitu suatu pendidikan yang dapat membekali peserta didik dengan kecakapan hidup yaitu keberanian menghadapi problema hidup dan kehidupan secara wajar tanpa merasa tertekan, kemudian secara kreatif menemukan solusi serta mampu mengatasinya. Pendidikan yang dapat mensinergikan berbagai mata pelajaran menjadi kecakapan hidup yang diperlukan seseorang, dimanapun ia berada, bekerja atau tidak bekerja, apa pun profesinya. Dengan bekal kecakapan hidup tesebut, diharapkan para lulusan akan mampu memecahkan problema kehidupan yang dihadapi, termasuk mencari atau menciptakan pekerjaan bagi mereka yang tidak melanjutkan pendidikannya (Depdiknas, 2002). Kendall dan Marzano (1997) menegaskan bahwa kecakapan hidup (life skills) telah menjadi salah satu hal yang harus dimiliki dan dikuasi oleh masyarakat, termasuk peserta didik, agar mereka mampu berperan aktif dalam lapangan kerja yang ada serta mampu berkembang.

Lebih lanjut dikemukakan oleh Indrajati Sidi (2002) bahwa kecakapan hidup lebih luas dari keterampilan untuk bekerja, dan dapat dipilah menjadi lima, yaitu: (1) kecakapan mengenal diri (self awarness), yang juga disebut kemampuan personal (personal skill), (2) kecakapan berpikir rasional (thingking skill), (3) kecakapan sosial (social skill), (4) kecakapan akademik (academic skill) dan (5) kecakapan vokasional (vocational skill).

Tiga kecakapan yang pertama dinamakan General Life Skill (GLS), sedangkan dua kecakapan yang terakhir disebut Specific Life Skill (SLS). Di dalam kehidupan nyata, antara GLS dan SLS antara kecakapan mengenal diri, kecakapan berpikir rasional, kecakapan sosial, kecakapan akademik dan kecakapan vokasional tidak berfungsi secara terpisah-pisah atau tidak terpisah secara ekslusif. Hal yang terjadi adalah peleburan kecakapan-kecakapan tersebut, sehingga menyatu menjadi sebuah tindakan individu yang melibatkan aspek fisik, mental, emosional dan intelektual. Derajat kualitas tindakan individu dalam banyak hal dipengaruhi oleh kualitas kematangan berbagai aspek pendukung tersebut di atas.

Tujuan pendidikan kecakapan hidup adalah memfungsikan pendidikan sesuai dengan fitrahnya, yaitu mengembangkan potensi manusiawi peserta didik untuk menghadapi perannya di masa datang. Secara khusus, pendidikan yang berorientasi kecakapan hidup bertujuan: (1) mengaktualisasikan potensi peserta didik sehingga dapat digunakan untuk memecahkan problema yang dihadapi, (2) memberikan kesempatan kepada sekolah untuk mengembangkan pembelajaran yang fleksibel, sesuai dengan prinsip pendidikan berbasis luas, dan (3) mengoptimalisasikan pemanfaatan sumber daya di lingkungan sekolah, dengan memberikan peluang pemanfaatan sumber daya yang ada di masyarakat, dengan 
prinsip manajemen berbasis sekolah (Indrajati Sidi, 2002).

Dari uraian di atas maka dapat disarikan bahwa kecakapan hidup (life skills) adalah kemampuan yang diperlukan untuk menempuh kehidupan dengan sukses, bahagia dan secara bermartabat, seperti kemampuan berpikir, berkomunikasi secara efektif, membangun kerjasama, melaksanakan peran sebagai warga negara yang bertanggungjawab dan kesiapan untuk terjun di dunia kerja.

\section{SISWA BELAJAR KEHIDUPAN DAN ILMU PENGETAHUAN}

Jika ditanya "untuk apa anak harus sekolah", jawaban yang biasa muncul "biar pandai". Jika ditanya lagi "mengapa anak perlu pandai" biasanya dijawab "biar hidupnya nanti sukses". Jadi pandai hanyalah alat untuk mengantarkan seseorang menjadi sukses. Tentu saja sukses dalam berbagai dimensinya, baik dilihat dari profesi atau pekerjaan yang ditekuni, kehidupan pribadi/keluarga dalam keagamaan dan kemasyarakatan.

Kemampuan yang diperlukan agar seseorang dapat hidup dengan sukses (sebagai pribadi, sebagai hamba Tuhan, sebagai anggota masyarakat/bangsa/ negara) itulah yang disebut dengan kecakapan hidup (life skills). Beberapa ahli mendefinisikan kecakapan hidup sebagai kemampuan untuk menghadapi problema kehidupan, kemudian secara proaktif mengatasinya secara arif dan kreatif (Depdiknas, 2004). Definisi ini bertolak dari asumsi bahwa dalam kehidupan kita selalu dihadapkan dengan masalah, karena masalah adalah kesenjangan antara harapan dengan kenyataan. Masalah itulah yang harus diantisipasi dan diselesaikan secara arif dan kreatif. Kita akan sukses dalam kehidupan, jika mampu melakukan prediksi masalah yang akan muncul dan secara proaktif mengasinya secara arif dan kreatif. Kita akan sukses jika mampu secara kreatif mengubah masalah menjadi peluang. Oleh karena itu, kecakapan hidup itulah yang seharusnya menjadi orientasi pendidikan. Dengan cara itu, peserta didik yang telah menyelesaikan suatu jenjang pendidikan, dapat menggunakannya untuk menghadapi kehidupan nyata di lapangan.

Untuk mengembangkan kecakapan hidup, anak perlu mempelajari mata pelajaran tertentu, misalnya untuk belajar kearifan anak perlu belajar agama, PPKn, dan sebagainya. Untuk mampu membuat perhitungan tertentu, siswa perlu belajar Matematika dan seterusnya. Namun tetap harus diingat bahwa penguasaan materi ajar bukanlah tujuan tetapi alat untuk membentuk kecakapan hidup. Jangan sampai siswa hanya belajar mata pelajaran, tanpa mengetahui bagaimana menggunakannya, secara terintegrasi dengan mata pelajaran lain, untuk memahami dan memecahkan problema kehidupan.

Dengan pola pikir tersebut berarti pendidikan haruslah fungsional, yang berarti apa yang dipelajari seharusnya dapat dimanfaatkan oleh siswa dalam kehidupan. Seperti kata pepatah bijak dalam bahasa latin "non scholae sed vitae discimus" yang artinya: kita belajar bukan untuk sekolah, tetapi untuk hidup. Finch dan Crunkilton (1979) juga mengingatkan bahwa pendidikan itu pada dasarnya education for life pada pendidikan yang bersifat umum dan educatif for earning a living pada pendidikan kejuruan. Jadi menurut dia, pendidikan itu untuk kehidupan atau untuk mendapatkan penghasilan untuk kehidupan.

Dalam ajaran Islam, Allah mendorong setiap orang untuk belajar, tetapi bukan memberikan pahala yang berlipat, jika apa yang dipelajari tersebut di- 
aplikasikan dalam kehidupan. Tentu saja, dalam kehidupan yang sesuai dengan prinsip agama dan itulah yang dimaksudkan kearifan dalam menerapkan ilmu. Dua kecakapan hidup yang fungsional untuk masa depan anak. Bukan belajar untuk belajar, tetapi belajar untuk mengembangkan kecakapan kehidupan, demi perannya di masa depan.

Beberapa ahli melakukan identifikasi apa saja yang dicakup dalam kecakapan hidup. Namun yang paling mudah dipahami adalah menggunakan pola pikir induktif, yaitu mencermati orang-orang yang dianggap sukses dalam kehidupannya dan kemudian dilakukan generalisasi. Pencermatan seperti itu menemukan kecakapan kunci orang sukses antara lain: jujur, kerja keras, disiplin, kreatif, pantang menyerah, menguasai bidang yang dikerjakan, tanggung jawab pandai melihat peluang, pandai berkomunikasi, pandai bekerjasama dengan orang lain dan berani mengambil resiko. Ketika kesuksesan tersebut dilebarkan ke dalam kehidupan bermasyarakat, biasanya muncul kecakapan kunci; toleransi dan suka membantu sesama, aktif dalam aktivitas kemasyarakatan dan sebagainya.

Jika yang dicermati adalah orang sukses dalam bidang lain atau tolok ukur kesuksesan yang digunakan berbeda, sangat mungkin ditemukan aspek kecakapan hidup yang berbeda pula. Tetapi dari diskusi dengan beberapa teman, ternyata aspek-aspek tersebut berlaku untuk berbagai profesi. Bahkan, kecakapan kunci tersebut juga berlaku bagi persayaratan untuk promosi bagi karyawan di berbagai perusahaan.

Beberapa orang mempertanyakan apakah kecakapan hidup tidak menyempitkan makna pendidikan, karena seakan-akan pendidikan hanya untuk mencari pekerjaan seperti pada pendidikan kejuruan. Dalam konteks ini, perlu dipahami bahwa kehidupan jauh lebih luas daripada bekerja dalam arti mencari penghasilan. Sikap jujur, tanggungjawab, kerja keras, ulet, cerdas, kreatif, pandai berkomunikasi dan bekerjasama tidak hanya diperlukan bagi mereka yang mencari penghasilan. Ibu rumah tangga dan para pensiunan tetap memerlukan kecakapan tersebut, walaupun mereka tidak bekerja dalam arti mencari penghasilan. Bahkan anak yang masih sekolah juga memerlukan kecakapan tersebut, demi keberhasilan sekolahnya.

Konsep pendidikan kecakapan hidup sebenarnya justru "meluruskan" kembali praktek pendidikan yang selama ini menganggap seakan-akan pendidikan adalah untuk upaya menguasai ilmu yang dipelajari dalam mata pelajaran/mata kuliah. Lebih menyedihkan, kemudian hasil pendidikan juga hanya diukur dari penguasaan mata pelajaran secara kognitif dan parsial. Oleh karena itu dapat dipahami mengapa perilaku siswa/mahasiswa bahkan lulusan seperti yang diilustrasikan pada bagian pendahuluan.

\section{KECAKAPAN HIDUP DAN KURI- KULUM PENDIDIKAN}

Depdiknas (2004) merinci kecakapan hidup menjadi kecakapan hidup generik dan kecakapan hidup spesifik. Kecakapan hidup generik, dirinci (1) kesadaran diri, (2) kecakapan berpikir, (3) kecakapan komunikasi dan (4) kecakapan bekerjasama. Kesadaran diri banyak terkait dengan sikap dan dirinci menjadi (a) kesadaran diri sebagai hamba Tuhan, yang diwujudkan dengan ibadah ritual maupun sikap hidup yaitu: jujur, disiplin, tanggung jawab, kerja keras dan ulet/pantang menyerah; (b) kesadaran diri sebagai makhluk sosial, yang diwujudkan dengan toleransi dan menghormati orang lain, serta berempati dan memberikan bantuan kepada sesama 
manusia, (c) kesadaran diri sebagai bagian dari lingkungan, yang diwujudkan dengan memelihara lingkungan dan menggunakannya secara bijak, dan (d) kesadaran akan potensi diri sebagai karuniah Tuhan, yang diwujudkan dalam mengenal kekuatan dan kelemahan diri, mengembangkan potensi diri, serta bekerja keras.

Kecakapan berpikir dirinci menjadi kecakapan: (a) menggali informasi melalui berbagai sumber, (b) mengolah informasi, (c) mengambil keputusan, dan (d) menyelesaikan masalah secara arif dan kreatif. Kecakapan komunikasi diwujudkan dalam (a) komunikasi lisan, melalui menyimak dan berbicara, serta (b) komunikasi tulis, melalui membaca dan menulis. Kecakapan kerjasama, diwujudkan dalam kecakapan (a) bekerjasama dengan rekan setara, dan (b) bekerjasama dalam posisi sebagai anggota tim, dan (c) bekerjasama dalam posisi sebagai pimpinan tim. Di samping itu ada kecakapan spesifik, yang menunjuk dalam bidang yang ditekuni.

Implementasi pendidikan kecakapan hidup dapat mempertimbangkan beberapa model, antara lain adalah: (1) model integratif, (2) model komplementatif, dan (3) model diskrit (Saryono, Djoko: 2002). Dalam model integratif, implementasi pendidikan kecakapan hidup melekat dan terpadu dalam program-program kurikuler, kurikulum yang ada, dan atau mata pelajaran yang ada. Berbagai program kurikuler dan mata pelajaran yang ada seharusnya bermuatan atau berisi kecakapan hidup. Model ini memerlukan kesiapan dan kemampuan tinggi dari sekolah, kepala sekolah, dan guru mata pelajaran. Kepala sekolah dan guru harus pandai dan cekatan menyiasati dan menjabarkan kurikulum, mengelola pembelajaran, dan mengembangkan penilaian. Ini berarti, mereka harus kreatif, penuh inisiatif dan kaya gagasan. Keuntungannya, model ini relatif murah, tidak membutuhkan ongkos mahal, dan tidak menambah beban sekolah terutama kepala sekolah, guru, dan peserta didik.

Dalam model komplementatif, implementasi pendidikan kecakapan hidup dimasukkan dan atau ditambahkan ke dalam program pendidikan kurikuler dan struktur kurikulum yang ada; bukan mata pelajaran. Pelaksanaannya bisa berupa menambahkan mata pelajaran kecakapan hidup dalam struktur kurikulum atau menyelenggarakan program kecakapan hidup dalam kalender pendidikan. Model ini tentu saja membutuhkan waktu tersendiri, guru tersendiri di bidang kecakapan hidup dan ongkos yang relatif besar. Selain itu, penggunaan model ini dapat menambah beban tugas siswa dan guru selain beban finansial sekolah. Meskipun demikian, model ini dapat digunakan secara optimal dan intensif untuk membentuk kecakapan hidup pada peserta didik.

Dalam model diskrit, implementasi pendidikan kecakapan hidup dipisahkan dan dilepaskan dari program-program kurikuler, kurikuler reguler, dan atau mata pelajaran (pembelajaran kurikuler). Pelaksanaannya dapat berupa pengembangan program kecakapan hidup yang dikemas dan disajikan secara khusus kepada peserta didik. Penyajiannya bisa terkait dengan program kokurikuler atau bisa juga berbentuk program ekstrakurikuler. Model ini membutuhkan persiapan yang matang, ongkos yang relatif besar dan kesiapan sekolah yang baik. selain itu, model ini memerlukan perencanaan yang baik agar tidak salah penerapan. Meskipun demikian, model ini dapat digunakan membentuk kecakapan hidup peserta didik secara komprehensif dan leluasa.

Menurut Parjono (2002) model pembelajaran pendidikan life skills di sekolah dibagi menurut jenjang sekolah sebagai berikut: 
1. Untuk peserta didik itngkat SD dan SLTP dilakukan dengan mengintegrasikan paket-paket diklat provokasional melalui reorganisasi materi pembelajaran dan penetapan bahan ajar minimal agar dapat menguasai general life skill. Program ini diharapkan dapat memberikan wawasan yang luas tentang dunia kerja dan karir, sehingga kalau akan memilih sekolah selanjutnya sudah memiliki pilihan yang tepat.

2. Bagi peserta didik SMU ditawarkan paket-paket diklat yang diperlukan masyarakat melalui reorganisasi materi pembelajaran dan menetapkan bahan ajar minimal agar dapat menguasai generasi life skills. Selain itu juga ditawarkan program kecakap-an vokasional (vocational skills) yang akan memberikan bekal kepada mereka untuk dapat bekerja atau menciptakan pekerjaan sendiri setelah selesai sekolah. Sementara untuk peserta didik SMK kecakapan vokasional telah menjadi isi kurikulum, sehingga mereka perlu kecakapan generik dan kecakapan akademik.

Model manapun yang dipilih, yang penting adalah bahwa pembelajaran kecakapan hidup tersebut pada hakekatnya adalah pembelajaran yang menempatkan siswa sebagai pelaku belajar. Siswa mempunyai kesempatan untuk belajar aktif, baik mental maupun fisik, dan hal ini dapat diperoleh bila lingkungan belajar dibuat menyenangkan bagi siswa.

Model pembelajaran yang dimaksud adalah model pembelajaran aktif. Model pembelajaran aktif merupakan model pembelajaran yang membuat siswa melakukan perbuatan untuk beroleh pengalaman, interaksi, komunikasi, dan refleksi. Siswa akan belajar banyak melalui perbuatan beroleh pengalaman langsung. Dengan berbuat, siswa mengaktifkan lebih banyak indera daripada hanya melalui mendengarkan. Selanjutnya kecakapan interaksi akan dimiliki oleh siswa bila pelajaran berlangsung dalam suasana interaksi dengan orang lain, misalnya berdiskusi dan tanya jawab. Sedangkan kecakapan komunikasi merupakan kecakapan untuk mengungkapkan pikiran dan perasaan, baik secara lisan maupun tulisan dan hal ini menjadi kebutuhan setiap manusia dalam rangka mengungkapkan gagasannya kepada orang lain dan mendapat tanggapan maka orang itu akan merenungkan kembali gagasannya, kemudian melakukan perbaikan, sehingga memiliki gagasan yang lebih mantap. Inilah yang dimaksud refleksi. Refleksi ini dapat terjadi sebagai akibat dari interaksi dan komunikasi.

Temuan dari Tim Peneliti Universitas Negeri Malang (2002) mengenai faktor-faktor penghambat pendidikan kecakapan hidup di Jawa Timur menunjukkan bahwa faktor internal yang berasal dari guru, sistem sekolah, kurikulum, serta fasilitas yang dimiliki sekolah merupakan faktor penghambat yang utama. Faktor penghambat yang lain juga termasuk faktor eksternal yang berasal dari dukungan pemerintah, sosial/budaya, dukungan dunia usaha/industri dan dukungan orang tua. Hasil penelitian itu juga menjelaskan bahwa menurut peringkatnya, guru menduduki peringkat pertama sebagai penghambat, disusul berturut-turut oleh sistem sekolah, kurikulum, fasilitas, dukungan pemerintah, dukungan dunia usaha/industri, orang tua, dan sosial budaya.

Faktor penghambat dari guru meliputi guru kurang mengerti pendidikan kecakapan hidup, kurang profesional dalam mengajar, tidak mempunyai keterampilan khusus, gaji rendah, motivasi untuk berkembang rendah dan kurang tekun dalam mengembangkan diri. Faktor penghambat sistem sekolah meliputi sistem yang sering beruba-ubah, 
tidak mendukung pelaksanaan pendidikan kecakapan hidup, kurang terpadu antar jenjang, dan kurang waktu dalam pembinaan keterampilan siswa.

Selanjutnya faktor penghambat kurikulum meliputi terlalu sarat materi, kurang sesuai dengan aset unggulan daerah, masih seragam terpusat, tidak mengarah kepada pendidikan kecakapan hidup serta mengabaikan minat dan bakat siswa. Faktor penghambat dari sisi fasilitas meliputi fasilitas kurang memadai, fasilitas yang ada kurang mendukung pendidikan kecakapan hidup, dan fasilitas tidak merata antara sekolah meskipun untuk jenjang sekolah yang sama.

Sementara itu faktor penghambat dukungan pemerintah meliputi bantuan dana tidak merata, relatif kecil, nara sumber ahli pendidikan kecakapan hidup sedikit, bantuan yang ada kurang mendukung pelaksanaan program pendidikan kecakapan hidup. Sedangkan faktor penghambat dukungan dunia industri adalah meliputi keterbatasan jumlah serta sumber daya dunia usaha/industri di daerah, merasa tidak mempunyai ikatan, tidak ada akad kerjasama yang jelas, alokasi waktu sekolah dengan dunia usaha/industri yang tidak seiring dan tidak ada koordinasi.

Kemudian mengenai faktor penghambat sosial/budaya adalah meliputi tatanan sosial/budaya yang tidak mendukung siswa sekolah bekerja, tidak memahami pendidikan kecakapan hidup, serta masih berorientasi pada perolehan gelar sesudah selesai sekolah. Penghambat bagi orang tua meliputi kebanyakan berpendapatan rendah sedangkan yang berpendapatan tinggi kurang sadar, tidak mengerti pendidikan kecakapan hidup, pola pikir berorientasi pada gelar kesarjanaan dan motivasi untuk mendorong anak memperoleh kecakapan hidup rendah.

Jelaslah bahwa banyak faktor penghambat yang sangat mungkin di- hadapi oleh sekolah dalam rangka implementasi pendidikan kecakapan hidup, baik itu faktor internal dari sekolah sendiri maupun faktor eksternal. Memperhatikan kendala-kendala tersebut, maka di dalam implementasi pendidikan kecakapan hidup di sekolah, tahap awal yang harus dilakukan adalah memberikan pengertian dan pemahaman kepada pelaksana sekolah (terutama guru dan kepala sekolah) mengenai pendidikan kecakapan hidup itu sendiri. Hal ini penting karena berdasarkan temuan di atas, ternyata faktor guru merupakan salah satu penghambat utama, yang antara lain karena guru kurang mengerti pendidikan kecakapan hidup, kurang profesional dalam mengajar, tidak mempunyai keterampilan khusus, dan kurang tekun dalam mengembangkan diri. Implementasi pendidikan kecakapan hidup di sekolah, tidak akan berhasil dengan baik bila berbagai kendala di atas, terutama yang terkait dengan faktor guru, belum diatasi lebih dahulu.

Pengenalan kecakapan hidup terhadap peserta didik bukanlah untuk mengganti kurikulum yang ada, akan tetapi melakukan reorientasi terhadap kurikulum yang ada agar benar-benar dapat merefleksikan nilai-nilai kehidupan nyata. Jadi pendidikan kecakapan hidup merupakan upaya untuk menjembatani kesenjangan antara kurikulum yang ada terhadap tuntutan kehidupan nyata.

Keberhasilan implementasi pendidikan kecakapan hidup tidak hanya bergantung pada model yang digunakan, namun juga sangat bergantung pada terpenuhi tidaknya syarat-syarat minimal yang harus diupayakan untuk masingmasing model. Model-model implementasi di atas sifatnya adalah kondisional, oleh sebab itu, pihak sekolah perlu memilih dan menggunakannya secara hati-hati sesuai dengan kondisi, kemampuan dan keinginan sekolah beserta seluruh stakeholder-nya. Model mana- 
pun yang dipilih, implementasi pendidikan kecakapan hidup membutuhkan suatu reorientasi kurikulum, pembelajaran, dan penilaian (Saryono, Djoko, 2002). Selain itu juga memerlukan reformasi manjemen sekolah, budaya sekolah, dan peningkatan hubungan sekolah dengan masyarakat.

Aspek-aspek kecakapan hidup, khususnya yang bersifat sikap (merupakan perwujudan kesadaran diri) banyak yang sebenarnya merupakan bagian aktivitas sehari-hari manusia. Secara teoritik aspek sikap atau ranah afektif lebih efektif jika dikembangkan melalui kebiasaan sehari-hari. Misalnya disiplin pada siswa akan lebih mudah dikembangkan jika disiplin telah menjadi kebiasaan sehari-hari di sekolah. Jujur, kerja keras, saling toleransi dan sebagainya akan mudah dikembangkan jika aspek-aspek tersebut sudah menjadi kebiasaan sehari-hari di sekolah. Ibarat anak yang memasuki gedung yang bersih, tentu sungkan kalau akan membuang sampah di sembarang tempat. Jika kepala sekolah dan guru selalu datang di kelas beberapa menit sebelum pelajaran dimulai, tentu secara bertahap siswa akan mengikutinya. Jika kepala sekolah dan guru biasa membaca dan kemudian membuat rangkuman yang ditempel di majalah dinding sekolah, akan mendorong siswa menirunya. Jika antara guru dan karyawan terjadi kebiasaan saling menyapa dan menghormati bahkan saling menolong akan menubuhkan hal serupa pada siswa.

Dari contoh di atas, budaya sekolah memang harus dirancang dan dilakukan dengan keteladanan. Kepala sekolah, guru, karyawan dan bahkan orang tua siswa dapat berunding bagaimana memulai dan mengembangkan budaya itu. Pada jenjang tertentu, siswa juga dapat dilibatkan untuk merancang dan memutuskan budaya apa yang akan dikembangkan, termasuk sangsi apa yang diberikan bagi mereka yang tidak mematuhinya.

Mungkin ada yang mengatakan sangat sulit untuk mengembangkan budaya seperti itu. Tetapi dari pengamatan, ternyata juga ada beberapa sekolah yang telah berhasil dan ternyata sekolah yang berhasil mengembangkan budaya seperti mampu hasil belajar siswa juga sangat bagus. Di beberapa negara budaya sekolah (school culture) juga sedang menjadi kajian untuk meningkatkan mutu. Mungkin kita dapat mendahuluinya dengan mengaitkan dengan gagasan kecakapan hidup.

\section{PENUTUP}

Implementasi kecakapan hidup di sekolah dapat dimasukkan dalam mata pelajaran muatan lokal, sehingga tidak menambah beban bagi guru dan sekolah. Kecakapan hidup dalam pengembangan kurikulum lebih merefleksikan kehidupan nyata, penyelenggaraannya benarbenar memiliki penguasaan kehidupan yang kuat, siswa aktif dan mempelajari kenyataan, metode pembelajaran lebih konkrit, kerja tim kuat, media pendidikan menggunakan kenyataan, tempat belajar tidak harus di kelas, pembelajaran tergantung kompetensi yang ingin dikuasai, pengalaman hidup lebih nyata dan evaluasi belajar lebih menekankan pada kenyataan.

Implementasi pendidikan kecakapan hidup harus ditangani secara hati-hati, serius, dan cermat. Kesalahan dalam penanganan hanya akan memunculkan masalah baru dalam pendidikan. Sebaliknya penanganan yang benar akan membuat sebagai besar permasalahan pendidikan sekaligus permasalahan sosial-ekonomi masyarakat dapat diatasi. Ini berarti keberhasilan atau kegagalannya sangat bergantung pada para pelaku pendidikan itu sendiri, pakar-pakar pendidikan, birokrat, dan semua stakeholder pendidikan. 


\section{DAFTAR RUJUKAN}

Bambang Sartono. 2003. Pengenalan Pelatihan Kewirausahaan dalam Rangka Pendidikan Berorientasi Kecakapan Hidup, Semiloka Pengembangan Model Pembelajaran, Lembaga Penelitian UNY, 13 Agustus 2003

Brolin, D.E. 1989. Life Centred Career Education: A Competency Based Approach. Reston VA: The Council for Exeptional Children.

Depdiknas RI. 2004. Pendidikan Kecakapan Hidup: Buku I Edisi 2. Jakarta: Depdiknas RI

Dinas Pendidikan Jawa Barat. 2002. Pendidikan Berbasis Luas Kecakapan Hidup dengan Model Pelaksanaan Pembelajaran Hidup di Sekolah. Bandung: Dwi Rama.

Eun-Sonn Baik \& Namhee Kim. 2003. Life Skills Development From the Perspective of Korea. Makalah pada Asian Approach to Life Skills Development di Seoul Korea, Tanggal 9-12 Desember 2003

Finch, Curtis R \& John R. Crunkilton. 1979. Curriculum Development in Vocational and Teachnical Education. Boston: Allyn and Bacon Inc.

Inciong, Teresita G. 2003. Life Skills Development in the Philippines. Makalah pada Asia Approach to

Indeks

budaya $79,80,81$

guru $77,79,80,81$

kurikulum $73,77,78,79,80,81$

media. 81

model $77,78,80$

pelajaran... $72,74,75,76,77,78,80,81$
Life Skills Development di Seoul Korea, Tanggal 9-12 Desember 2003.

Indrajati Sidi. 2002. Konsep Pendidikan Berorientasi Kecakapan Hidup (Life Skills) melalui Pendidikan Berbasis Luas (Broad-Based Education-BBE), Direktorat Jenderal Pendidikan Dasar dan Menengah Departemen Pendidikan Nasional

Kendall, John S dan Marzano, Robert J. 1997. Content Knowledge: A Compedium of Standards and Benchmarkes for K-12 Education. Aurora, Colorado, USA: Mc REL Mid - Continent Regional Education Laboratory, Alexandria, Virginia, USA: ASCD

Parjono. 2002. Upaya Meningkatkan Kualitas Pendidikan melalui Pendidikan Kecakapan Hidup (Life Skills). WUNI, Edisi Mei 2002. LPM Universitas Negeri Yogyakarta.

Saryono, Djoko. 2002. Pendidikan Kecakapan Hidup: Konsepsi dan Implementasinya di Sekolah. Makalah dalam Workshop Pengembangan Sistem pendidikan Dasar dan Menengah Berorientasi Kecakapan Hidup di Jawa Timur, 11 Nopember 2002, Universitas Negeri Malang.

pendidikan $72,73,74,75,76,77,78,79$, $80,81,2$

sekolah ..... 73, 75, 76, 77, 78, 79, 80, 81 sistem ............................... 73, 74, 79 siswa... 72, 73, 75, 76, 77, 78, 79, 80, 81 solusi 73,74 